PROFESI (Profesional Islam)

Media Publikasi Penelitian; 2018; Volume 15; No 2.

Website: ejournal.stikespku.ac.id

\title{
Kajian Formulasi, Karakteristik Fitokimia dan Sensori Es Krim Jamu Tradisional Beras Kencur
}

\author{
Nurul Hidayah * \\ Prodi D III Keperawatan Akademi Keperawatan Pemkab Ngawi \\ *Email: nurulridlo@gmail.com
}

\begin{abstract}
Kata Kunci
Formulasi;

Karakteristik

Fitokimia;

Sensoris es krim

jamu beras kencur.
\end{abstract}

\begin{abstract}
Abstrak
Jamu merupakan obat tradisional Indonesia yang saat ini kurang diminati oleh masyarakat, karena bentuk sediaan yang kurang menarik. Penelitian ini bertujuan membuat formulasi sediaan jamu menjadi es krim jamu sehingga dapat meningkatkan kembali minat masyarakat terhadap jamu. Varian rasa jamu yang dipilih adalah beras kencur. Penelitian ini menguji 3 formula yang digunakan sebagai bahan utama pembuat es krim. Formula I menggunakan susu kental manis dan gelatin, formula II menggunakan susu UHT, skim, santan dan gelatin, formula III menggunakan susu full krim, santan dan gelatin. Analisis data yang digunakan adalah uji organoleptik, analisis kandungan gizi, dan analisis persentase angka kecukupan gizi. Hasil analisis produk menunjukkan bahwa formula II menghasilkan produk es krim beras kencur yang lebih banyak disukai dan penampilan visual yang lebih baik dibandingkan formula I dan III serta Es krim formula II memenuhi Nilai Standar Nasional Indonesia untuk komposisi Es krim sehingga layak untuk dipasarkan.
\end{abstract}

\section{The Study of Formulation, Phytochemicals Characteristics and Sensory of Traditional Herb Ice Cream Beras Kencur}

\author{
Keywords \\ Formulation; \\ Characteristics \\ Phytochemicals; \\ Sensory Beras \\ Kencur Traditional \\ Herb Ice Cream.
}

\begin{abstract}
Herb is an Indonesian traditional medicine that is currently less desirable by the society, because of the less interesting appearance. The aim this study is to make the formulation of herbal medicine appearance into herb ice cream in order to increase the society's interest against herb. The selected herbal flavour variant was beras kencur. This study tested three formulas which were used as the main ingredients of ice cream. Formula I used sweetened condensed milk and gelatin, formula II used UHT milk, skim, coconut milk and gelatin, formula III used full cream milk, coconut milk and gelatin. Data analyses used were organoleptic test, nutritional content analysis, and nutrient adequacy rate analysis. The product analysis results showed that formula II produced more preferred beras kencur ice cream products and better visual appearance than formula I and III and Ice cream with formula II meet Indonesian National Standard Value for ice cream composition so it was worth to be marketed.
\end{abstract}

\section{PENDAhuluan}

Jamu merupakan salah satu jenis obat tradisional asli dari Indonesia yang cukup dikenal olah masyarakat kita. Kebiasaan minum jamu sudah menjadi budaya bangsa Indonesia sejak dulu. Budaya ini diwariskan turun-temurun, sehingga terus tumbuh dan berkembang di kalangan masyarakat Indonesia. Hingga saat ini di Indonesia terdapat 1012 industri jamu, 901 diantaranya masih merupakan industri kecil. Hal ini menunjukkan bahwa perkembangan industri jamu di Indonesia masih kurang meskipun jamu 
merupakan salah satu dari budaya lokal masyarakat kita (Kardiyono, 2005).

Selama ini sediaan produk jamu banyak dikenal dalam bentuk sediaan siap minum, jamu serbuk, dan sediaan simplisia kering yang diseduh. Seiring dengan perkembangan teknologi yang diikuti dengan perubahan gaya hidup manusia yang menuntut segala sesuatunya serba cepat, menarik tetapi juga lezat, maka sediaan jamu tradisional tersebut dirasa kurang menarik, jika dibandingkan dengan perkembangan sediaan minuman lainnya, sehingga minat masyarakat terhadap jamu relatif rendah. Selain itu rasa jamu yang cenderung monoton juga menjadi alasan kurang minatnya konsumen terhadap jamu. Konsumen jamu banyak berkisar pada orangorang tua dan yang tinggal di pedesaan. Segmen pasar jamu untuk konsumen anak kecil masih kurang, sehingga budaya minum jamu lambat laun berpotensi menghilang. Oleh karena itu perlu dilakukan pengembangan dan inovasi dari produk-produk jamu tradisional yang sudah ada, salah satunya yaitu es krim dari jamu tradisional. Es krim jamu merupakan salah satu produk minuman beku yang dibuat dari bahan krim atau sejenisnya yang digabungkan dengan jamu (Maskuri, 2002). Es krim jamu ini diharapkan mampu menjangkau semua segmen, dan meningkatkan minat konsumen terhadap jamu. Dengan mengolah jamu menjadi es krim yang sehat dan bergizi tinggi diharapkan dapat meningkatkan minat masyarakat terhadap jamu dan secara tidak langsung melestarikan budaya bangsa kita yang kaya akan minuman tradisional yang berkhasiat. Melalui penelitian ini, dibuat formulasi jamu beras kencur dalam bentuk es krim, yang kemudian dikenal dengan istilah "es kriminal atau es krim minuman tradisional".

Komposisi jamu untuk bahan dasar es krim terdiri dari kencur, jahe, dan secang. Kencur (Kaempferia galanga L) termasuk satu dari lima jenis tumbuhan yang dikembangkan sebagai tanaman obat asli di Indonesia (Erlina et al, 2007). Kencur mengandung miyak atsiri dan secara empirik sering digunakan sebagai obat tradisional untuk mengurangi peradangan, obat batuk, gatal-gatal pada tenggorokan, perut kembung, mual-mual, masuk angin, pegal-pegal, pengompres bengkak, tetanus dan penambah nafsu makan (Sukari et al., 2008; Miranti, 2009). Penelitian Sulaiman et al, 2007 menyatakan bah- wa rimpang kencur juga berkhasiat menurunkan tekanan darah penderita hipertensi, rematoid artritis dan asma.

Rimpang jahe mengandung minyak atsiri $0,25-3,3 \%$ gingerols serta shogaols yang menimbulkan rasa pedas (Rismunandar, 1988). Rimpang jahe banyak digunakan untuk pengobatan radang lambung, masuk angin, menambah nafsu makan, muntah-muntah, kholera, perut sakit, rematik, bengkak-bengkak, terkilir, difteri, memperlancar peredaran darah, gangguan syaraf dan penghangat badan (Darwis et al., 1991; Paimin dan Murhananto, 1991).

Kayu secang (Caesalpinia sappan L) sebagai minuman herbal digunakan untuk pengobatan darah kotor, antidiabetik, anti-tumor, antimikroba, antivirus, antikoagulan antiinflamasi, dan sebagai immuno stimulan yang bersifat sitotoksik (Badami S et al, 2004: Sundari et al, 1998). Uji fitokimia diketahui bahwa secang mengandung senyawa fenol sangat tinggi, kadar terpenoid sangat tnggi dan kadar flavonoid tinggi (Widowati, 2011).

Dari uraian data diatas membuktikan bahwa jamu yang telah digunakan secara turun-temurun berkhasiat meningkatkan kesehatan. Melalui penelitian ini diharapkan masyarakat bisa mendapatkan cita rasa yang berbeda dalam menikmati jamu sehingga dapat meningkatkan minat masyarakat Indonesia terhadap minuman tradisional dalam bentuk es krim jamu yang diberi nama ES kriminal. Selain itu melalui formulasi pengolahan dan penyajian yang tepat diharapkan es krim jamu ini dapat menjadi alternatif pilihan konsumsi minuman yang sehat dan berkwalitas bagi kesehatan.

\section{METODE PENELITIAN}

Rancangan percobaan

a. Penelitian ini menggunakan metode percobaan dengan rancangan acak lengkap pola faktorial dengan $1 \times 3$ faktor. Faktor pertama adalah formula jamu beras kencur dan formula lainnya adalah bahan dasar es krim formula I,II dan III

b. Waktu penelitian

Penelitian ini dilakukan pada bulan November-Desember 2017

c. Tempat penelitian

Untuk pembuatan es krim dilakukan di laboratorium AKPER PemKab Ngawi, sedangkan 
PROFESI (Profesional Islam)

Media Publikasi Penelitian; 2018; Volume 15; No 2.

Website: ejournal.stikespku.ac.id

analisis kimia es krim dilakukan di Laboratorium Pusat Studi Pangan Dan Gizi Universitas Gadjah Mada Yogyakarta

Alat dan Bahan penelitian

a. Alat yang digunakan yaitu panci, pisau, sendok, baskom, timbangan, mixer blender, kompor dan peralatan analisis

b. Bahan utama yang digunakan dalam formulasi es krim ini adalah susu kental manis, susu skim, susu full krim, telur ayam, gula pasir, santan kelapa, tepung maizena, gelatin, rimpang kencur, beras, secang

Prosedur penelitian

a. Pembuatan jamu beras kencur

1. Bahan:

Beras $2 \mathrm{sdm}$, kencur $7 \mathrm{~cm}$, jahe $7 \mathrm{~cm}$, kedawung 5biji, secang 1 gr, gula aren $200 \mathrm{~g}$, garam $1 / 2 \mathrm{sdt}$, air $700 \mathrm{ml}$.
2. Prosedur pembuatan:

a) Cuci beras dan tiriskan, kemudian sangrai

b) Sangrai biji kedawung

c) Blender beras bersama kencur dan jahe

d) Rebus kedalam air dan tambahkan secang, kedawung, gula pasir dan gula aren

e) Saring, ambil $600 \mathrm{ml}$

b. Pembuatan Es krim Beras kencur

Penelitian menggunakan tiga formula untuk membuat es krim jamu beras kencur. Perbedaan formula terdapat pada bahan baku pembuatan es krim. Formula bahan utama es krim jamu ditunjukkan pada tabel 1

Tabel 1. Formula bahan utama es krim jamu beras kencur.

\begin{tabular}{cllllll}
\hline No & \multicolumn{2}{c}{ Formula 1 } & \multicolumn{2}{c}{ Formula 2 } & \multicolumn{2}{c}{ Formula 3 } \\
\hline 1 & \multicolumn{1}{c}{ Bahan } & \multicolumn{1}{c}{ Jumlah } & \multicolumn{1}{c}{ Bahan } & \multicolumn{1}{c}{ Jumlah } & \multicolumn{1}{c}{ Bahan } & \multicolumn{1}{c}{ Jumlah } \\
\hline 2 & Air & $200 \mathrm{ml}$ & Air & $200 \mathrm{ml}$ & Air & $200 \mathrm{ml}$ \\
\hline 3 & Maizena & $3 \mathrm{sdm}$ & Maizena & $3 \mathrm{sdm}$ & Maizena & $3 \mathrm{sdm}$ \\
\hline 4 & Telur ayam & $1 \mathrm{butir}$ & Telur ayam & $1 \mathrm{butir}$ & Telur ayam & $1 \mathrm{butir}$ \\
\hline 5 & $\begin{array}{l}\text { Susu kental } \\
\text { manis }\end{array}$ & $370 \mathrm{gr}$ & Susu UHT & $250 \mathrm{ml}$ & $\begin{array}{l}\text { Susu full } \\
\text { krim } \\
\text { serbuk }\end{array}$ & \\
\hline 6 & & & & & \\
\hline 7 & & & Susu skim & $125 \mathrm{~g}$ & & \\
\hline 8 & Gelatin & $1 \mathrm{sdm}$ & Santan cair & $130 \mathrm{ml}$ & Santan cair & $195 \mathrm{ml}$ \\
\hline 9 & & Gelatin & $1,5 \mathrm{sdm}$ & Gelatin & $2 \mathrm{sdm}$ \\
\hline
\end{tabular}

Cara membuatnya:

Formula I: siapkan wadah untuk memasak (panci/wajan), masukkan air $200 \mathrm{ml}$ kedalam panci, maizena, telur dan ramuan jamu beras kencur, aduk terus dan masak hingga lengket. Pindahkan ketempat yang lebih besar, setelah itu biarkan sampai dingin. Masukkan $1 \mathrm{sdm}$ SP, dan 1 kaleng susu kental manis. Blender hingga mengembang. Pindahkan ke wadah lainnya dan simpan dalam freezer hingga setengah beku. Setelah itu mixer kembali hingga 3 kali.

Formula II: siapkan wadah untuk memasak (panci/wajan), masukkan air $200 \mathrm{ml}$ kedalam panci, maizena, telur, santan, gula pasir dan ramuan jamu beras kencur, aduk terus dan masak hingga lengket. Pindahkan ketempat yang lebih besar, setelah itu biarkan sampai dingin. Setelah dingin masukkan 1,5 sendok makan SP, dan $125 \mathrm{~g}$ susu skim, susu UHT, blender hingga mengembang. Pindahkan ke wadah lainnya dan simpan dalam freezer hingga setengah beku. Setelah itu mixer kembali hingga 3 kali.

Formula III : siapkan wadah untuk memasak (panci/wajan), rebus air $200 \mathrm{ml}$, ramuan jamu beras kencur, gula pasir 14 sendok, santan, susu telur, dan maizena, aduk terus dan masak hingga lengket. Pindahkan ketempat yang lebih besar, setelah itu biarkan sampai dingin. Masukkan 2 sendok SP, blender hingga mengembang. Pindahkan ke wadah lainnya dan simpan dalam freezer 
PROFESI (Profesional Islam)

Media Publikasi Penelitian; 2018; Volume 15; No 2.

Website: ejournal.stikespku.ac.id

hingga setengah beku. Setelah itu mixer kembali hingga 3 kali.

c. Pengemasan es krim

Produk es krim dikemas dalam paper cup ukuran $100 \mathrm{ml}$, dan disimpan dalam lemari pendingin pada suhu dibawah $4^{0} \mathrm{c}$ agar tidak mencair

\section{HASIL DAN PEMBAHASAN}

Penelitian ini menggunakan 3 formula sebagai bahan baku es krim yang ikut menentukan bentuk dan konsistensi es krim yang dihasilkan. Uji yang dilakukan pada produk meliputi uji organoleptik, analisis kimia pada es krim, serta analisis persentase angka kecukupan gizi. Uji organoleptik es krim jamu beras kencur dilakukan pada 35 responden yang diberikan kuesioner dan sampel es krim jamu. Pada penilaian ini es krim formula I diiberi Kode A, formula II diberi kode B dan es krim formula III diberi kode C. Penilaian kuesioner meliputi rasa yang enak, penampilan yang menarik, bau, tekstur yang lembut dengan memberikan nilai pernyataan berupa sangat setuju, setuju, tidak setuju dan sangat tidak setuju terhadap sampel es krim yang dirasakan.

Hasil rekapitulasi pendapat responden tentang formulasi I, II, III dapat dilihat pada tabel berikut:

Tabel 2: hasil rekapitulasi uji organoleptik es kriminal formula I

\begin{tabular}{llllllllll}
\hline & Skala penilaian & \multicolumn{2}{c}{ Sangat Setuju } & & \multicolumn{2}{c}{ Setuju } & \multicolumn{2}{c}{ Tidak Setuju } & \multicolumn{2}{c}{ Sangat Tidak Setuju } \\
\hline 1 & Jumlah & $\mathrm{n}$ & $\%$ & $\mathrm{n}$ & $\%$ & $\mathrm{n}$ & $\%$ & $\mathrm{n}$ & $\%$ \\
\hline 2 & Rasa & 7 & 20 & 18 & 51 & 6 & 17 & 4 & 11 \\
\hline 3 & Bau & 2 & 5.7 & 12 & 34.2 & 17 & 48 & 4 & 11 \\
\hline 4 & Tekstur & 12 & 34,2 & 14 & 40 & 8 & 22 & 1 & 2.8 \\
\hline 5 & Penampilan & 9 & 25.7 & 18 & 51 & 6 & 17 & 2 & 5.7 \\
\hline 6 & Warna & 5 & 14.2 & 20 & 57 & 9 & 25 & 1 & 2.8 \\
\hline
\end{tabular}

Sumber: data primer

Tabel 3: hasil rekapitulasi uji organoleptik es kriminal formula II

\begin{tabular}{rlllllllll}
\hline No & Skala penilaian & \multicolumn{2}{c}{ Sangat Setuju } & \multicolumn{2}{c}{ Setuju } & \multicolumn{2}{c}{ Tidak Setuju } & \multicolumn{2}{c}{ Sangat Tidak Setuju } \\
\hline 1 & Jumlah & $\mathrm{n}$ & $\%$ & $\mathrm{n}$ & $\%$ & $\mathrm{n}$ & $\%$ & $\mathrm{n}$ & $\%$ \\
\hline 2 & Rasa & 20 & 57 & 13 & 37 & 1 & 2.8 & 1 & 2.8 \\
\hline 3 & Bau & 7 & 20 & 17 & 48.5 & 10 & 28.5 & 1 & 2.8 \\
\hline 4 & Tekstur & 19 & 54 & 16 & 45 & 0 & 0 & 0 & 0 \\
\hline 5 & Penampilan & 10 & 28,5 & 18 & 51 & 7 & 20 & 0 & 0 \\
\hline 6 & Warna & 7 & 20 & 20 & 57 & 8 & 22 & 0 & 0 \\
\hline
\end{tabular}

Sumber: data primer

Tabel 4: hasil rekapitulasi uji organoleptik es kriminal formula III

\begin{tabular}{rlllllllll}
\hline No & Skala penilaian & \multicolumn{2}{c}{ Sangat Setuju } & \multicolumn{2}{c}{ Setuju } & \multicolumn{2}{c}{ Tidak Setuju } & \multicolumn{2}{c}{ Sangat Tidak Setuju } \\
\hline 1 & Jumlah & $\mathrm{n}$ & $\%$ & $\mathrm{n}$ & $\%$ & $\mathrm{n}$ & $\%$ & $\mathrm{n}$ & $\%$ \\
\hline 2 & Rasa & 13 & 37 & 15 & 42 & 6 & 17 & $\mathrm{I}$ & 2.8 \\
\hline 3 & Bau & 2 & 5,7 & 14 & 40 & 17 & 48 & 2 & 5.7 \\
\hline 4 & Tekstur & 4 & 11 & 7 & 20 & 15 & 42 & 9 & 25,7 \\
\hline 5 & Penampilan & 8 & 22 & 16 & 45 & 11 & 31 & 0 & 0 \\
\hline 6 & Warna & 7 & 20 & 20 & 57 & 8 & 22,8 & 0 & 0 \\
\hline
\end{tabular}

Sumber: data primer

Dari tabel 2,3,4 diatas dapat disimpulkan bahwa pada es krim formula I,II dan III dari segi rasa, bau, tekstur penampilan dan warna sebagian besar responden lebih menyukai formula II dibandingkan dengan formula I, dan III. Untuk penilaian rasa sebanyak 20 orang $(57 \%)$, bau 
PROFESI (Profesional Islam)

Media Publikasi Penelitian; 2018; Volume 15; No 2.

Website: ejournal.stikespku.ac.id

sebanyak 17 orang $(48,5 \%)$, tekstur sebanyak 19 orang $(54 \%)$, penampilan 18 orang $(51 \%)$, dan warna 20 orang $(57 \%)$. Selain itu penggunaan bahan baku juga ikut mempengaruhi rasa, penampilan visual dan tekstur es krim. Hal ini dikarenakan kandungan kimia pada masingmasing bahan berbeda sehingga berpengaruh pada es krim yang dihasilkan, seperti yang tersaji pada tabel 5 .

Tabel 5 hasil uji organo-leptik es krim formula I,II, dan III

\begin{tabular}{ccl}
\hline No & Formula & \multicolumn{1}{c}{ Hasil } \\
\hline 1 & Formula I & $\begin{array}{l}\text { Rasa susu lebih menonjol, tekstur kurang homogen (masih ada butir- } \\
\text { butir lemak yang terdispersi) }\end{array}$ \\
\hline 2 & Formula II & $\begin{array}{l}\text { Rasa susu tidak terlalu menonjol, rasa jamu menonjol, tidak bikin enek, } \\
\text { pas lembutnya }\end{array}$ \\
\hline 3 & Formula III & $\begin{array}{l}\text { Rasa susu tidak menonjol, rasa jamu menonjol, terlalu kental, terlalu } \\
\text { lembut dan manis }\end{array}$ \\
\hline
\end{tabular}

Formula II menghasilkan es krim yang lebih baik dibandingkan dengan formula I dan III. Tekstur es krim formula II lebih lembut serta emulsi dan warna lebih homogen dibandingkan dengan Formula I dan III. Hal ini dikarenakan formula I lebih banyak mengandung zat yang tidak mudah larut dalam air, sehingga pembentukan emulsinya sulit terjadi. Selain itu rasa jamu pada formula I kurang karena tertutupi rasa susu yang lebih menonjol, sedangkan pada formula II rasa jamu mengalahkan rasa santan. Pada formula III rasa jamu menutupi rasa susu tetapi lebih kental, terlalu lembut dan manis, hal ini dikarenakan pemakaian santan yang lebih dominan sehingga menghasilkan emulsi yang lebih padat.
Analisis kandungan gizi hanya dilakukan pada es krim yang memiliki rasa dan penampilan menarik yaitu Formula II. Produk es krim jamu beras kencur dianalisis sifat kimianya di laboratorium Pusat Studi Pangan dan Gizi Universitas Gadjah Mada. Analisis dilakukan oleh pihak laboratorium sesuai dengan prosedur laboratorium yang bersangkutan. Jenis pemeriksaan meliputi Kadar air dan abu dengan metode Gravimetri, lemak dengan metode Soxhlet, protein dengan metode Kjeldahl, dan karbohidrat dengan metode pengurangan. Hasil analisis kandungan gizi dapat dilihat pada tabel 6 .

Tabel 6 Kandungan gizi es krim Formula II

\begin{tabular}{lllll}
\hline No & \multicolumn{1}{c}{ Macam analisis } & \multicolumn{2}{c}{ Hasil Analisis } & \multicolumn{1}{c}{ Rata-rata } \\
\hline 1 & Air & 63,26 & 63,33 & 63,29 \\
\hline 2 & Abu & 0,21 & 0,32 & 0,26 \\
\hline 3 & Protein & 2,07 & 1,89 & 1,98 \\
\hline 4 & Lemak & 2,76 & 3,13 & 2,94 \\
\hline 5 & Karbohidrat by-diff & 31,70 & 31,37 & 31,53 \\
\hline 6 & Kalori total (kal 100g) & 159,95 & 161,05 & 160,5 \\
\hline 7 & Gula & 19,38 & 18,97 & 19,17 \\
\hline
\end{tabular}

Sumber: data primer

Dari tabel diatas dapat dilihat pada es krim jamu terdapat kandungan protein sebesar $1,98 \%$, lemak $2,94 \%$, karbohidrat $31,53 \%$, yang mana ketiganya merupakan makronutrien yang diperlukan oleh tubuh. Selain itu kadar abu menunjukkan kandugan mineral pada produk ini sebesar $0.25 \%$. Mineral merupakan salah satu mikronutrien yang diperlukan oleh tubuh. Hasil analisis kandungan gizi es krim jamu kemudian dibandingkan dengan AKG untuk acuan pelabelan pangan umum menurut keputusan Kepala Badan Pengawasan Obat dan Makanan Nomor HK.00.05.52.6291. Analisis prosentase angka kecukupan gizi (\%AKG) dapat dilihat pada tabel 7 berikut: 
PROFESI (Profesional Islam)

Media Publikasi Penelitian; 2018; Volume 15; No 2.

Website: ejournal.stikespku.ac.id

Tabel 7. Persentase AKG Setiap 100g dari Es Krim Jamu Formula II

\begin{tabular}{clll}
\hline No & Kandungan & Jumlah (gram) & $\%$ AKG \\
\hline 1 & Lemak & $3,17 \mathrm{~g}$ & $8,15 \%$ \\
\hline 2 & Protein & $3,17 \mathrm{~g}$ & $2,76 \%$ \\
\hline 3 & Karbohidrat & $3,15 \mathrm{~g}$ & $9,22 \%$ \\
\hline 4 & Total Gula & $23,892 \mathrm{~g}$ & $7,07 \%$ \\
\hline 5 & Energi total 161,41 Kkal & \\
\hline 6 & Energi dari lemak 28,53 Kkal & & \\
\hline
\end{tabular}

AKG berfungsi sebagai pedoman dalam pemenuhan gizi per hari. Persentase AKG dihitung supaya konsumen dapat mengestimasi jumlah dan jenis makanan yang dikonsumsi untuk memenuhi kebutuhan gizinya. Persentase AKG produk menunjukkan bahwa es krim jamu ini memiliki nilai kalori sebesar 161,41 Kkal setiap takaran saji $100 \mathrm{~g}$ sehingga dapat digunakan sebagai makanan tambahan yang menyehatkan selain karena kandungan herbalnya.

Di Indonesia Standar Nasional komposisi es krim yang memenuhi syarat mutu es krim adalah lemak minimum 5 persen, gula dihitung sebagai sakarosa minimum 8 persen, protein minimum 2,7 persen dan jumlahan padatan minimum 3,4 persen (Hartatie, 2013). Untuk prosentase AKG lemak sebesar $8,15 \%$, protein sebesar $2,76 \%$, dan gula sebesar 7,07\% sudah memenuhi Standar Nasional Indonesia untuk komposisi Es krim. Persentase AKG untuk mineral tidak dapat dihitung karena analisis kandungan kimia untuk mineral tidak spesifik. Dari produk Es krim jamu ini secara keseluruhan mempunyai kandungan gizi yang mencukupi sehingga layak untuk dipasarkan.

\section{KESIMPULAN}

1. Es krim formula II yang terdiri dari maizena telur, susu UHT, susu skim, santan, gelatin, gula pasir, air dan ramuan jamu beras kencur menghasilkan produk es krim yang lebih enak dibandingkan dengan formula I dan III

2. Es krim formula II memenuhi Nilai Standar Nasional Indonesia untuk komposisi Es krim sehingga layak untuk dipasarkan

\section{REFERENSI}

Badami S, Moorkoth S, Suresh B, 2004. Caesalpinia sappan a medicinal and dye yielding plant. Nat Product radiance;3(2):75-82.8.

Darwis, A. B. D. Indomadjo, dan S. Hasiyah. 1991. Tumbuhan Obat Famili Zingiberacaea. Pusat Penelitian Pengembangan Pertanian. Bogor.

Erlina, R., A. Indah, dan Yanwirasti. 2007, Efek Antiinflamasi Ekstrak Etanol Kunyit (Curcuma domesticaVal.) pada Tikus Putih Jantan Galur Wistar, J. Sains dan Teknologi Farmasi, 12:2, 112-115.

Hartatie, E.S, 2011. Kajian formulsi (bahan baku, bahan pemantap) dan metode pembuatan terhadap kualitas es krim. Jurnal Gamma .7 (1): 20-26.

Kardiyono, 2005, prospek dan peluang nature based products sebagai komoditas unggulan memasuki era perdagangan bebas. Seminar Nasional Prospek herbal dan makanan Fungsional untuk kesehatan. Surakarta.LPPM UNS:26-36

Maskuri, 2002, Teknologi pembuatan es krim. Modul Materi kuliah. Semarang: Fakultas Peternakan Universitas Diponegoro:

Miranti, L., 2009, Pengaruh Konsentrasi Minyak Atsiri Kencur (Kaempferia galanga L.) dengan Basis Salep Larut Air terhadap Sifat Fisik Salep dan Daya Hambat Bakteri Staphylococcus aureus secara In vitro. Skripsi.Universitas Muhamadiyah Surakarta. 
PROFESI (Profesional Islam) Media Publikasi Penelitian; 2018; Volume 15; No 2.

Website: ejournal.stikespku.ac.id

Paimin, F. B. dan Murhananto. 1991. Budidaya Pengolahan dan Perdagangan. Penebar Swadaya. Jakarta.

Rismunandar. 1988. Rempah-rempahKomoditi Ekspor Indonesia. Sinar Baru. Bandung.

Sukari, M. A., N. W. M. Sharif, A. L. C. Yap, S. W. Tang, B. K. Neoh, M. Rahmani, G. C. L. Ee, Y. H. Taufiq-Yap, and U. K. Yusof, 2008, Chemical Constituens Variations of Essential Oils from Rhizomes of Four Zingiberaceae Species, The Malaysian J. Anal. Sci., 12(3), 638-644.
Sulaiman, M. R., Z. A. Akaria, I. A. Daud, F. N. Ng, Y.C. Ng, and M. T. Hidayat, 2007, Antinociceptive and Anti-inflammatory Activities of the Aqueous Extract of Kaempferia galanga Leaves in Animal Models. J. Nat. Med.,62, 221-227.

Sundari D, Widowati L, Winarno MW, 1998, Informasi khasiat, keamanan dan fitokimia tanaman secang (Caesalpinia sappanl.) warta tumbuhan obat Indonesia. The Journal on Indonesian Medicinal Plants.4(3):1-2.

Widowati. 2011, Uji Fitokimia dan Potensi Antioksidan Ekstrak Etanol Kayu Secang (Caesalpinia sappan L.), JKM, $11(1): 23-31$ 